\title{
Natural Dyes Product Design Using Green Quality Function Deployment II Method To Support Batik Sustainable Production
}

\author{
Dyah Ika Rinawati ${ }^{1, *}$, Diana Puspita Sari ${ }^{1}$, Darminto Pujotomo ${ }^{1}$ and Puji Handayani Kasih ${ }^{1}$ \\ ${ }^{1}$ Department of Industrial Engineering, Faculty of Engineering, Diponegoro University, Semarang - Indonesia
}

\begin{abstract}
Using synthetic dyes causes bad impact on the environment. But using natural dyes has several problems such as fade, slight colour variations and takes longer time. In order to solve that problems, it is needed to develop instant natural dyes. This study aims to design instant natural dyes to fulfill needs of batik artisans that having minimal environmental impact as well as having minimal cost. This study use green quality function deployment II method. This study involve voice of customer identification, calculation gap, the determination of characteristic of technical, making the house of quality (HOQ), life cycle assessment (formulation of green house \& green the matrix), life cycle cost (formulation of cost house, the preparation of cost the matrix) and concept comparison house ( $\mathrm{CCH})$. Based on voice of customer, natural dyes that will be developed is red colour. Red natural dyes extracted from root of Morinda citrifolia and Ceriops candolleana. In this research, there are two alternatives of natural dyes namely powders and liquid natural dyes. The result of this study is powder natural dyes selected because of lower environmental impact and user operational cost.
\end{abstract}

Keywords: Batik; Natural Dye; Green Quality Function Deployment II.

\section{Introduction}

Batik is a fabric dying method using wax to create patterns and designs. This method makes use of a resist technique; applying areas of cloth with wax (a dyeresistant substance) to prevent them from absorbing colours when the cloth is dipped into dye. Not only as a dye-resistant substance, wax is applied to control the dye from spreading out from a particular area to create motif when the dye is painted [1]. Two processes that represent the art of batik making are 'batik-tulis' (hand-drawn batik) and 'batik cap' (hand-stamped batik).

Batik is an important textile product that has recognized by UNESCO as Intangible Cultural Heritages (intangible wealth) of Indonesia in 2009. Batik industries generate a large contribution to Indonesia's economic development. However, batik industries also produce large amounts of waste cause of material-usage inefficiency in each phase of the production process. In practice, there was much water are used for each textile process of preparation, dyeing, rinsing and others [2]. Nowadays, majority of batik artisans still use synthetic dyes. Using synthetic dye in dyeing process of batik causes negative impact on environment as synthetic dyes are polluting agents that having carcinogenic properties and toxicity [3]. Most of the natural colourants are believed to be safe because of their non-toxic, nonallergic and biodegradable nature as compared with synthetic dyes [4].
Measurement the level of eco-efficiency products in batik industries using a life cycle assessment generated value under 1 [5], [6]. It's mean that the products are affordable but not sustainable. Activities that dominates the environmental costs are the colouring process with synthetic materials. This study suggests for the use of natural dyes as an alternative. However, in application of natural dyes has several problems such as fade, slight colour variations, takes longer time for dyeing process, and the complexity of the extraction technique of natural dyes. In order to solve that problems, it is needed to develop instant natural dyes. Natural dyes are widely marketed is blue colour made from Indigofera tinctoria. Based on previous research [3], [7], [8] there are many alternatives of natural dyes. So it is necessary to design the product of natural dyes according to the needs of consumers by consider aspect of quality, environmental and cost to support batik sustainable production.

\section{Methodology}

This research use Green Quality Function Deployment II method (QFD II) that integrate QFD (Quality Function Deployment) method with LCA (Life Cycle Assessment) and LCC (Life Cycle Cost).

\subsection{Quality Function Deployment (QFD)}

According to [9] Quality Function Deployment (QFD) is a method for planning and development of products that enable the development team to clearly 
define the customer wants and needs, and also to evaluate each proposed product or service capabilities systematically in relation the impact on the achievement of those needs. The first stage of data processing is to identify the voice of customer of instant natural colour criteria, then it will be translated into the language of technical (technical response). To find out information about the level of importance, satisfaction and expectations of respondents used a questionnaire. The questionnaire tested the validity and reliability testing. Next calculate the importance rating, the satisfaction level of satisfaction and expectations of the respondents as well as the Gap. The final phase on this stage is decide technical characteristic and make house of quality (HOQ).

\subsection{Life Cycle Assessment (LCA)}

According to [10] LCA is a tool used to evaluate the environmental impact of a product, process or activity. According [11] The concept of LCA is based on the premise that an industrial system is closely linked to the environment in which the industry is located. The industrial system consist of input and output. Input of the system in the form of material taken from the environment and its output will be discharged back into the environment. LCA in this study using Simapro 7.1 software with methods ecocost 2012 v3.3.

\subsection{Life Cycle Cost (LCC)}

According to [12] Life Cycle Cost shows the estimated cost from the beginning to the end of the equipment or a specified project to study the analysis and estimation of total costs in a given period by taking into account the time value of money. In this study LCC is used to evaluate the costs that incurred by the natural dyes product during its life cycle. LCC costs in this study consisted of capital expenditure and operational expenditure. Capital expenditure is the cost to purchase production equipment natural dyes, while operational expenditure consists of raw material costs, depreciation costs, labor costs, distribution costs and cost of electricity.

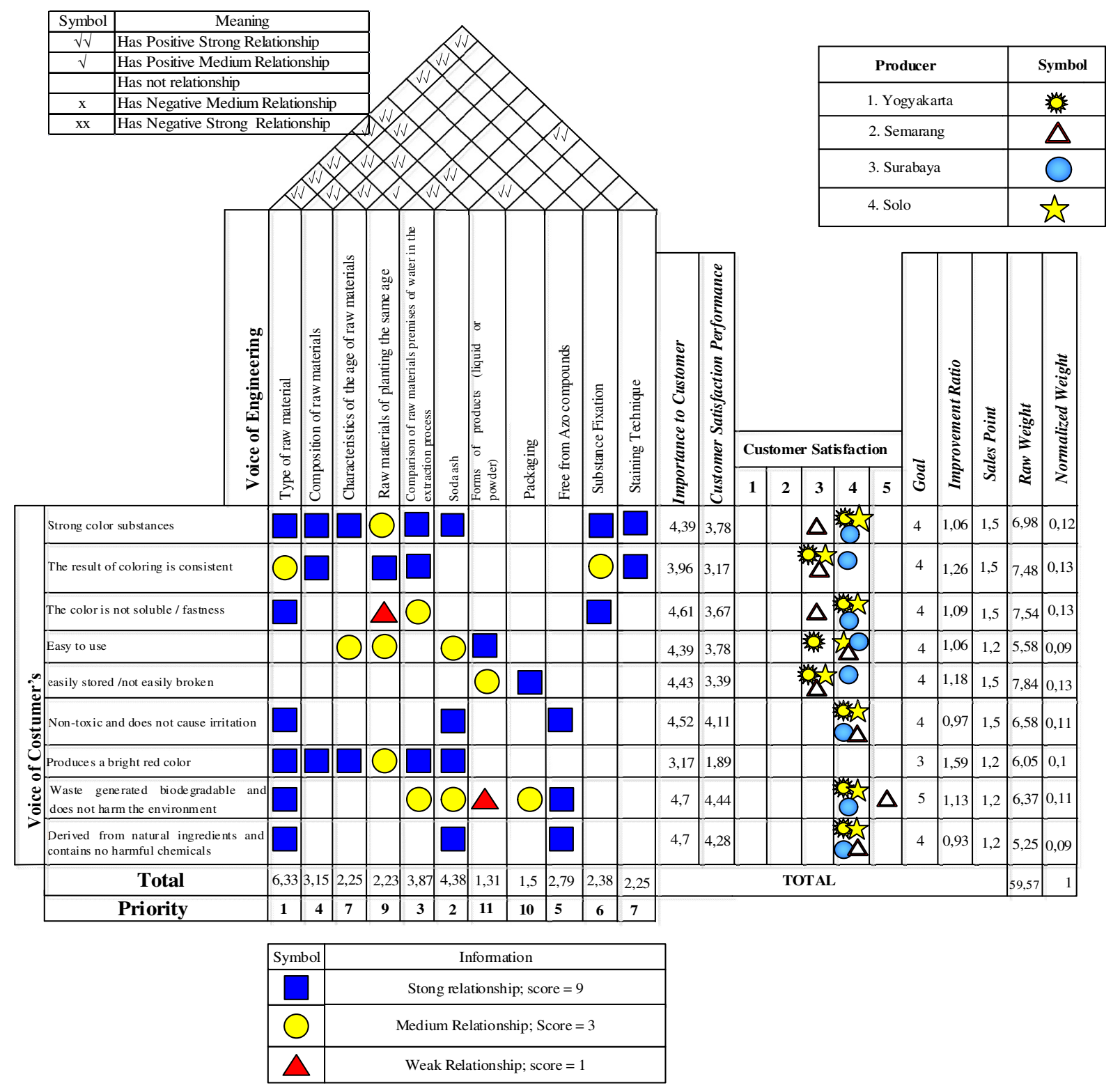

Fig. 1. House of Quality of Instant Natural Dyes 


\subsection{Green Quality Function Deployment II}

Quality Function Deployment (QFD) is a proven methodology to achieve total customer satisfaction. To address environmental issue, Cristofari et al. (1996) in [13] developed the method of Green QFD (GQFD), in which LCA and QFD are combined to evaluate different product concepts. Ref [13] Zhang (1999) developed Green QFD II that is integrate LCA, LCC and QFD into one efficient tool for deploying quality according to the needs and desires of consumers, the environment and the costs throughout the product development process. In this study consisted of two phases, namely the identification of technical response and develop product concepts. In technical response phase we developed three house, namely Quality House $(\mathrm{QH})$, which consists of voice of customer, Green House (GH) derived from LCA and Cost House $(\mathrm{CH})$ derived from the LCC. Then the data LCC and LCA of the product concept to be put into GM (green matrix) and CM (cost matrix). This phase aims to identify the technical response quality, environmental and cost through analysis based on products, requests the technical response is then used to develop new product concepts. The next phase is to develop the concept of the product. The purpose of this phase is to develop a series of alternative product concepts to meet the requirement that has been determined in phase I. These concepts and basic line in the product concept evaluation to select the concept of product design through Concept Comparison House (CCH).

\subsection{Size of datasets}

The population of voice customer identification in this study are SMEs (Small and Medium Enterprises) batik that use natural dyes in some regions in Indonesia, i.e. Semarang, Solo, Klaten and Yogyakarta as much as 23 respondents.

\section{Result}

\subsection{Quality Function Deployment}

Voice of Customer identified by interviewed 23 respondents. It's indicate that the instant natural dyes desired by batik artisans is red colour. Currently the instant natural dyes available are yellow powder from Terminalia bellirica, the brown powder of Peltophorum pterocarpum and blue colour powder and paste of Indigofera tinctorium. Instant natural dyes mostly used by Indonesian batik artisans are powder and paste blue colour made from Indigofera tinctorium.

In this study, data collection of consumer wants (natural colour batik artisans) were obtained through questionnaires. Variables used as a criterion of natural red dye products ready to use preliminary results obtained from the questionnaire and also based on [4] Results of the survey being quality attributes of natural dyes in accordance with the needs and wants of the natural colour batik artisans. Attribute quality natural dyes produced by the costumer wants that were divided into three groups, namely dimensional performance, aesthethic and environment. In each dimension has a different number of quality attributes in accordance with the expectation and needs of consumers. After getting the voice of customer and technical response the next stage is the preparation of the House of quality (HOQ) is shown in Fig. 1. Based HOQ known that the technical response is the most important raw materials used types of natural dyes. Based on the results of experiments that have been done on several alternatives of raw material, show that root of Noni (Morinda citrifolia) and bark of Tingi (Ceriops candolleana) gave the best dyeing result. So, that material being selected to be used in natural dye development. Furthermore, the second important attributes are auxiliaries in the extraction process soda ash. The use of soda ash help release the dye contained in the root of Noni (Morinda citrifolia). After that, the third priority is comparison of raw material premises of water in the extraction process. Comparison of raw materials is also important. And then the product should also be Azo free. Next priority is the application of substances fixation. The experimental results with some substance fixation showed that lime is the best fixer to generate red colour.

\subsection{Life Cycle Assessment (LCA)}

After getting the house of quality (HOQ), the next stage is life cycle assessment LCA. At this stage the environmental impact of the product life cycle of instant natural dyes will be evaluated.

The Life cycle inventory (LCI) of natural dyes consist of production, distribution and colouring batik.

1. Production : The production consist of extraction, evaporation, spray drying and packaging.

a. Extraction

The material for dye extraction are Tingi wood, Noni root and soda ash. The composition of raw materials are shown in Table 1.

b. Spray drying

Powder natural dyes manufacture by drying the extracted liquid using spray dryer machine with spray capacity $1500 \mathrm{ml}-2000 \mathrm{ml}$ per hour, with $4.2 \mathrm{Kwh}$ and also with a 310 Watt compressor engine.

c. Packaging

Packaging for liquid natural dye uses PET bottle and PP type bottle cap. At this stage required DK-50Z type covering machine with a power of 370 Watt with a capacity of 1200 bottles/ hour. While packaging for ZPA powder using plastic type LDPE with size $90 \mathrm{~mm} \times 130 \mathrm{~mm}$, and requires continuous sealer type FR $900 \mathrm{~V}$ engine with power 500 watts with a capacity of $12 \mathrm{~m} /$ minute.

2. Distribution : Distance shipments of powder natural dyes producer in Gunung Pati, Semarang to user in Yogyakarta is $121 \mathrm{~km}$. The product carried by trucks. 
3. Dyeing Process

Liquid natural dye can be directly used and does not require additional materials. While powder natural dye requires additional material that is 10 liters of hot water and 10 liters of normal water. $0,33 \mathrm{~kg}$ of LPG is used to heat water for mixing the powder dye.

LCI of natural dye made from Noni Root for 10 pieces batik fabric is given in Table 1. While Eco Costs of Natural Dye made from Noni Root given in Table 2.

Table 1. Life Cycle Inventory of Natural Dye made from Noni Root for 10 pieces batik fabric

\begin{tabular}{|l|l|l|l|}
\hline \multirow{2}{*}{\multicolumn{1}{|c|}{ Process }} & \multicolumn{3}{c|}{ Quantity of Input } \\
\cline { 2 - 4 } & Type of Input & \multicolumn{1}{c|}{ Liquid } & \multicolumn{1}{c|}{ Powder } \\
\hline Extraction & Noni Root & $4 \mathrm{~kg}$ & $2,86 \mathrm{~kg}$ \\
\hline Extraction & Tingi wood & $4 \mathrm{~kg}$ & $2,86 \mathrm{~kg}$ \\
\hline Extraction & Water & 40 liters & 28,6 liters \\
\hline Extraction & Soda Ash & $0,27 \mathrm{~kg}$ & $0,2 \mathrm{~kg}$ \\
\hline Extraction & LPG & $1,1 \mathrm{~kg}$ & $0,8 \mathrm{~kg}$ \\
\hline Extraction & $\begin{array}{l}\text { Electrical } \\
\text { energy }\end{array}$ & $2,5 \mathrm{Wh}$ & $1,08 \mathrm{Wh}$ \\
\hline Spray drying & $\begin{array}{l}\text { Electrical } \\
\text { energy }\end{array}$ & - & $\begin{array}{l}40.270 \\
\text { Wh }\end{array}$ \\
\hline Packaging & PET & $10 \mathrm{unit}$ & - \\
\hline Packaging & LDPE & & $10 \mathrm{unit}$ \\
\hline Packaging & $\begin{array}{l}\text { Electrical } \\
\text { energy }\end{array}$ & $3,08 \mathrm{Wh}$ & $0,625 \mathrm{Wh}$ \\
\hline Distribution & Gasoline & $\begin{array}{l}6,237 \\
\text { liters }\end{array}$ & $\begin{array}{l}6,237 \\
\text { liters }\end{array}$ \\
\hline Dyeing & Water & - & 20 liters \\
\hline Dyeing & Natural dye & 20 liters & $400 \mathrm{gram}$ \\
\hline Dyeing & LPG & - & $0,33 \mathrm{~kg}$ \\
\hline Dyeing & Electrical & - & $1,225 \mathrm{Wh}$ \\
\hline
\end{tabular}

\subsection{Life Cycle Cost}

Cost component that being analyzed in LCC are capital expenditure and operational expenditure. Which is included in capital expenditure are purchase of the equipment cost, while operational expenditure consists of material costs, depreciation costs, labor costs, electricity costs, cost of packaging and transportation costs. The equipment must be purchased to produce natural dye powder is water pumps, knives, stainless steel pans, gas stoves, gas cylinders, tool filters, cover engine of the bottle. While the equipment to be purchased for the production of liquid natural dyes are water pumps, knives, stainless steel pans, gas stoves, gas cylinders, plastic press machines, tools filter, spray dryer, and compressor. The matrix consists of cost house roof describes the relationship between costs arising in the product life cycle.

Table 2. Eco Costs of Natural Dye made from Noni Root

\begin{tabular}{|c|c|c|}
\hline \multirow{2}{*}{ Impact Category } & \multicolumn{2}{|c|}{ Eco Cost (Euro) } \\
\cline { 2 - 3 } & Liquid & Powder \\
\hline Total & 9,1507 & 7,5971 \\
\hline Climate change & 6,6645 & 5,4703 \\
\hline Acidification & 1,5847 & 1,3522 \\
\hline Ecotoxicity (freshwater) & 0,2303 & 0,2531 \\
\hline Human toxicity & 0,1050 & 0,0823 \\
\hline Fine dust & 0,1241 & 0,0730 \\
\hline Eutrophication & 0,1545 & 0,1331 \\
\hline Water Stress Indicator & 0,0298 & 0,0324 \\
\hline $\begin{array}{c}\text { Photochemical oxidant } \\
\text { formation }\end{array}$ & 0,2034 & 0,1936 \\
\hline Waste & 0,0544 & 0,0070 \\
\hline
\end{tabular}

\subsection{Concept Comparison House (CCH)}

Cost matrix aims to compare the cost of items that appear due to product life cycle of liquid and powder natural dyes. Cost item in the matrix is the cost of LCC calculation. After arranging the green matrix and cost matrix next stage is to develop $\mathrm{CCH}$ as shown in Fig. 2.

\section{Discussion}

$\mathrm{CCH}$ conducted to evaluate the difference between powder and liquid natural dyes based on factors of quality, environmental and cost. Referring to Figure 8, the selected product is powder natural dyes because although powder natural dye having greater manufacturing costs in the amount of natural dyes Rp 38.426 than liquid which has a cost manufacturing of $R p 7.676$, but powder natural dyes has satisfaction value of 789 while the liquid form of natural dyes has a value of 786 satisfaction, powder natural dyes has environmental impact value 7.597, while the liquid natural dyes have environmental impact value 9.151. Powder natural dyes have cost as much as Rp 613.338 consist of purchasing materials with additional costs such as electricity and LPG, while cost of using liquid natural dyes only for purchase materials amounted Rp 610.372. 


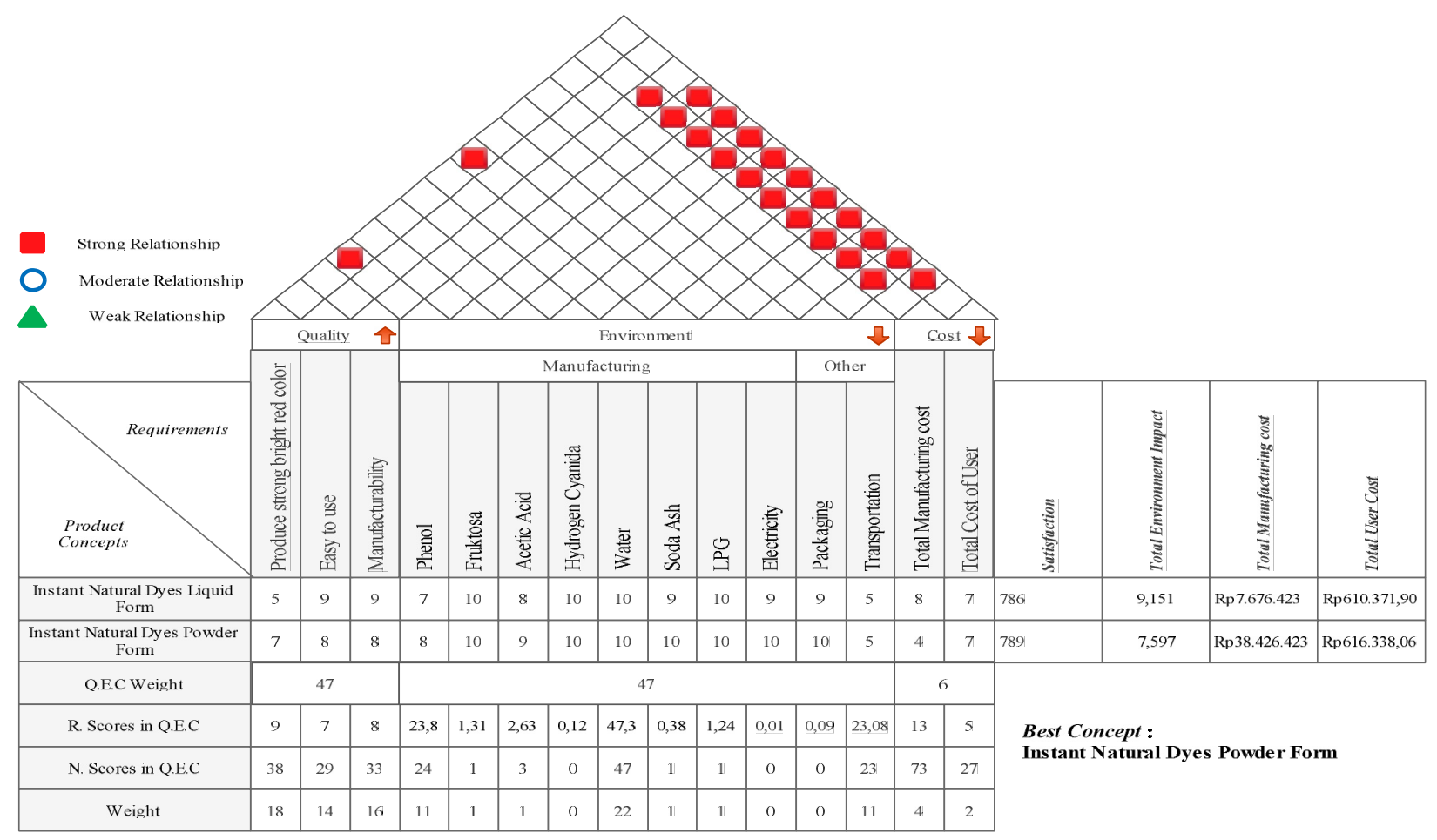

Fig. 2. Concept Comparison House $(\mathrm{CCH})$ of Natural Dyes

\section{Conclusion}

Priority criteria of natural dyes that suit batik artisans are instant natural dyes product that environmentally friendly and free from the chemicals hazardous, non-toxic and cause irritation, colour is not soluble / fastness, astringent colour strong, easy use, easily stored, producing a bright red colour, and consistent. Based on quality, environment and cost aspect, powder natural dyes is selected because it has higher satisfaction, have lower score of environmental impact even in cost of user is slightly more expensive. The designed product of natural dye can support our society in developing sustainable batik production. Finally, it can be stated that this research have contribution for establishing lowcarbon society.

\section{Acknowledgement}

This work has been funded by the Directorate of Research and Community Service, the Directorate General of Research Strengthening and Development, Ministry of Research Technology and Higher Education through grant for 'Hibah Bersaing'. That's in accordance assignment agreement implementation research number: 022 / SP2H / LT / DRPM / II / 2016 Date 17 February 2016. The authors wish to acknowledge the Head of Industrial Engineering Department, Dean of Faculty Engineeringand Head of LPPM of Diponegoro University for their support.

\section{References}

1 S. S. Oparinde, J. of Arts, Science \& Commerce, 3 2, 31-41, (2012)

2 N. Othman, J. of Hazardous Materials, 198, 103112, (2011).

3 U. R. Nanthini, A. Athinarayanan, R. A. J. A. Singh, Asian J. of Science and Tech. 4 9, 227230, (2013).

4 T. Bechhtold, A. Turcanu, E. Ganglberger, S. Geissler, J. of Cleaner Production 11 5, 499-509, (2003).

5 D. P. Sari, S. Hartini, D. I. Rinawati, T. S. Wicaksono, J. Teknik Industri 14 2, 137-144, (2012).

6 D. I. Rinawati, D. P. Sari, S. N. W. Pramono, F. Muljadi, S. P. Lestari, J. Teknik Industri Undip 8 1, 43-50. (2013).

7 A. Haji, J. of Chem. Eng. 29 3, 55-60. (2010)

8 Sutara, P. K., Jurnal Bumi Lestari 2, 217-223, (2009).

9 L. Cohen, Addison-Wesley Publishing Company. (1995)

10 Curran, M. A., Mc Graw Hill. (1996).

11 S. P. Astuti, U. Ciptomulyono, M. Suef, J. Teknik Industri 6 2, 156-168, (2004).

12 H. P. Barringer, E. Barringer, \& Associates, Inc, Proceedings of International Conference of Maintenance Societies (2003)

13 Y. Zhang, H. P. Wang, C. Zhang, Int. J. Production Research, 37 5, 1075-1091, (1999). 